\title{
Identification of Distribution Channels in the Supply Chain of Rice, Chili, Onion, Beef and Chicken Meat at Depok City
}

\author{
Sri Setiawati ${ }^{*}$, Silvia Ekasari ${ }^{1}$ and Marjan Miharja ${ }^{2}$ \\ ${ }^{1}$ STIE Manajemen Bisnis, Indonesia \\ ${ }^{2}$ STIH IBLAM, Indonesia
}

*Correspondence to: Sri Setiawati, STIE Manajemen Bisnis, Indonesia

\begin{abstract}
Supply chain which is a system that involves the production, delivery, storage, distribution and sales processes of products to meet demand. Distribution channels which are important in the supply chain, which are concerned with moving goods from one place to another effectively and efficiently. The purpose of this study was to identify the distribution channels of the supply chain for rice, chilies, shallots, beef and chicken in Depok City. The analytical method used is qualitative. Data collection techniques by means of observation, interviews and documentation. The results showed the distribution channel processes of rice, chilies, shallots, beef and chicken meat that occurred in Depok Cityhave to go through several hands including farmers, producers, distributors (traders) until it reaches consumers. Farmers in Depok City should cut the existing distribution channels by selling their crops directly to traders without going through collectors.
\end{abstract}

Keywords: supply chain; distribution channels; rice; chilies; shallots; beef and chicken

Article Received: 20 September 2020, Revised: 30 November 2020, Accepted: 18 December 2020

\section{Introduction}

The development of the Indonesian population which continues to increase, has implications for the increase in the need for basic commodities for the community. However, unfortunately Indonesian farmers have not been able to meet these basic needs both in quantity and quality. So that to meet these needs must be imported from other countries through the import policy of agricultural products.

In Indonesia, the problem of the distribution of goods and services is not only influenced by internal company problems but also by external problems such as infrastructure problems, such as smooth roads, technological aspects and so on. The agricultural industry is one of the most important sectors in the national economy, where the development of agricultural deposits is directed at increasing agricultural production in order to meet food needs and the needs of domestic industries.

Depok is one of the Government Cities in West Java Province, as an area bordering the capital city of Depok, is required to continue to improve in order to keep up with the accelerated pace of development in the capital area. Of course, the toughest challenge of this area is how local governments can improve the welfare of the community. Depok started from a sub-district in the area of Kewedanaan (Assistant to the Regent) in the Parung area of Bogor Regency, then in 1976 . Housing development began to be built by Perum Perumnas and developers which was then followed by the construction of the University of Indonesia (UI) campus.

With the increasingly rapid development and increasing trade and services requiring speedy services to fundamental problems in the regions, in 1981 the Government formed the Administrative City of Depok based on Government Regulation Number 43 of 1981 which was inaugurated on March 18, 1982 by the Minister of Home Affairs (H. Amir Machmud) which consists of 3 Districts and 17 Villages. With the increasingly rapid development and increasingly urgent demands of community aspirations, the Bogor Regency Government together with the West Java Provincial 
Government proposed to the Central Government and the Regional Representative Council to become a Municipality in the hope that services to the community would be better.

Most producers do not sell their goods directly to end users. Between producers and users there are distribution channels, groups of marketing intermediaries performing various functions and bearing various names. Some intermediaries such as wholesalers and retailers buy, take over rights, and resell the merchandise; they are called merchants . Others such as brokers, manufacturing representatives, and sales agents seek customers and can negotiate on behalf of the manufacturer but do not own the rights to the goods; they are called agents. Still others such as transportation companies, independent warehouses, banks, and advertising agencies assisting the distribution process but do not own the rights to the goods, do not negotiate purchases or sales; they are called facilitators.

A distribution channel is a series of interdependent organizations that are involved in the process of making goods or services ready for use or consumption. The distribution channel decision is one of the most critical decisions facing management. The channel the company selects greatly influences all other marketing decisions. The firm's pricing depends on whether the company uses bulk merchants or high-quality boutiques. Decisions about sales force and advertising depend on how much training and motivation a dealer needs. More than that, the company's distribution channel decisions involve a fairly long commitment to other companies. If a producer contracts independent distributors to sell its product, the producer cannot buy all of their shares the next day and replace them with the company's own shops (Kotler, 2002). Based on the description above, it can be said that distribution channels have a very important role in the company's marketing activities.

In Law Number 18 of 2012 the central and regional governments are responsible for the distribution of food according to their authority. The implementation of a flexible and efficient food distribution is one of the conditions for realizing food security.

One of the efforts to achieve food security at both the national and regional levels is the smooth distribution of food from producers to consumers. With the distribution of food was good expected in a $\mathrm{n}$ food can be available in sufficient quantities for both the number and diversity of the people all of the time. Adequacy of progress includes the availability of food continuously evenly distributed in every region and affordable to the purchasing power of the people.

Therefore, food distribution activities as a process of distributing food from producers accompanied by transfer of ownership, place and form are carried out by distribution or marketing agencies by implementing one or more of the marketing.

The variation in the ability of food producers between regions between seasons is a challenge in ensuring the distribution of food remains smooth throughout the region at all times. In many areas, the awareness and ability to manage the smooth distribution of food is limited, resulting in frequent instability of food supply and prices which have an impact on food security in the region. Depok City is an urban area with an area of approximately 101 hectares of rice fields that cannot meet basic food needs, it really depends on other areas. The need for rice in 1 year is 182,000 tons, while rice production in Depok City is less than 1,000 tons. In relation to the chili commodity, until now there has been no policy on the trading system of chili commodities so that the price movement is largely determined by the market mechanism. Chili price fluctuation occurs because chili production is seasonal. Furthermore, chili can fluctuate due to factors of rain, production costs and length of distribution channels. Meanwhile, the disparity of chili commodities between regions occurs due to the concentration of chili production centers outside the city of Depok and the inadequate quality of road infrastructure.

\section{Literature Review}

\section{Food Safety}


Law No. 7 of 1996 concerning food safety, Food is everything that comes from biological sources and water, whether processed or not, which is intended as food or beverage for human consumption, including food additives, food raw materials, and other materials used in the process of preparing, processing and or making food or beverages. Law No. 18 of 2012 concerning food Food distribution is an activity or a series of activities to distribute the food supply evenly at any time in order to meet the food needs of the community. Government Regulation No. 28 of 2004 on the safety, quality and nutrition, quality of food is the value determined on the basis of the criteria of food security, nutrition content and trade standard on foodstuffs, food and drinks. Government Regulation No. 17 of 2015 concerning Food security and food nutrition Article 59: "Government and Regional Government according to their authority are responsible for Food Distribution", namely:

- Development of a Food Distribution System that reaches all regions effectively and efficiently, including: development of food distribution infrastructure, facilities and institutions.

- Management of Food Distribution System, which can improve affordability of food, maintain safety, quality, nutrition, does not conflict with religion, beliefs and community culture, include: coaching, monitoring, surveillance, control, facilitation and incentives.

- Realization of smooth and safe Food Distribution, including regulation of: (1) flow of food distribution between islands, between provinces and between districts / cities; (2) food distribution and / or mobilization of food reserves from surplus areas to food shortage areas; (3) loading and unloading at ports, airports, stations and terminals

\section{Distribution Channel}

The distribution channel is a problem that the company will face when the product is finished processing. This distribution channel concerns how to get the product into the hands of consumers. The leadership of the company has a role in evaluating the appearance of the distributors. If the company plans a certain market, the first thing to think about is who will be appointed as the distributor there, or how many are willing to become distributors in the area. (Hahury, 2010)

One aspect that is very important and must be considered by every company is the selection of distribution channels, because errors in selecting this distribution channel can slow down and even hinder the distribution of goods from producers to consumers. (Ika Lis Mariatun, 2017).

According to Walters in Dharmmesta (1999), distribution channels are a group of traders and company agents who combine physical transfer and name of a product to create uses for a particular market. Kotler (2003), states, Marketing channels are sets of interdependent organizations involved in the process of making a product or service available for use or consumption. Another opinion also states, place (distribution) includes company activities to make products available to target consumers (Kotler \& Armstrong, 1997).

Bowersox (2006), American marketing association or American marketing association defines a distribution channel as a structure of organizational units between companies and agents and dealers extra companies, wholesalers, and retailers, through the name of the commodity, product or service. - marketed services. distribution channel is a group of intermediaries who are closely related to each other and who distribute products to buyers (Winardi, 1989: 299). From the understanding of the experts above, it can be concluded that the distribution channel is an activity of moving goods from producers to consumers effectively and efficiently in which, the process of distributing these goods can pass through various collaborations between producers, agents, wholesalers, and small traders and even producers. it could also cut the supply chain to sell directly to consumers.

Nitisemito (1993: 102), Distribution Channels are distributor agencies or channeling agencies that have activities to distribute or deliver goods or services from producers to consumers. Warren $\mathrm{J}$. Keegan (2003) Distribution channel is a channel 
used by producers to distribute these goods from producers to consumers or industrial users.

Assauri (1990: 3) Distribution channels are institutions that market products, in the form of goods or services from producers to consumers. Kotler (1991: 279) Distribution channels is a group of companies or individuals who have ownership rights over products or help transfer ownership rights to products or services when they are transferred from producers to consumers. Pujawan (2005: 5) explains that in a supply chain there are usually 3 types of flows that must be managed. The first is the flow of goods flowing from upstream (upstream) to downstream (downstream). The second is the flow of money and the like that flows from downstream to upstream. The third is the flow of information that can occur from upstream to downstream or vice versa. A business process and information that provides products or services from suppliers through the process of manufacture and distribution to consumers (Schoeder, 2007: 189). Judging from the understanding of several experts above, it can be concluded that the supply chain is a system that involves the process of production, delivery, storage, distribution and sale of products to meet demand. The supply chain includes all processes and activities involved in delivering the product to the end user (consumer). (Tulong, Tumbel, \& Palandeng, 2016).

\section{Nine Distribution Channel Functions}

Some of the main functions performed by distribution channel members include: information, promotion, negotiation, ordering, financing, risk taking, physical, payment, and ownership (Kotler, 2002) as follows:

\section{Information}

Furthermore, according to Kotler (2003), marketing channels gather information about potential and current customers, competitors, and other actors and forces in the marketing environment. Some important information collected by distribution channels:

- Customer
Information about customers that distribution channel members need to collect: customer needs, wants and requests. Some information about customers can be obtained through: interviews, questionnaires, surveys, and other sources of information (Kotler and Armstrong, 1997).

\section{- Competitor}

Information about competitors that distribution channel members need to collect: numbers and competitors (McCarthy, 1985), competitors' marketing strategies: what are their goals and strategies? what are their strengths and weaknesses? and how do they react to competitive strategies we may use? (Kotler and Armstrong, 1997).

\section{- Suppliers}

Suppliers are an important link in the "value delivery system" to all customers of a company. Suppliers provide the resources needed by the company to produce goods and services. An increase in supply prices can force companies to increase prices which can reduce sales volume (Kotler and Armstrong, 1997).

\section{Promotion}

Promotion is an activity that communicates product excellence and persuades target customers to buy it (Kotler and Armstrong, 1997).

The following describes the forms of promotion that can be used by distribution channels:

- Samples: a. free offer on a number of products and services.

- Coupon: a certificate that entitles the holder to a reduced price as printed when buying a particular product.

- Price package (discount-rupiah transaction): offers consumers savings from the usual price by getting a product that is stated on the label or package.

1. A reduced-price pack, which is a single package sold at a reduced price (such as: buy one for two).

2. Package bond (banded pack), two products related fused together (such as: toothbrush and toothpaste). 
- Prizes (contests, sweepstakes, games): a prize is an offer of an opportunity to win cash, travel or goods for buying something.

\section{Negotiation}

According to Kotler (2003), marketing channels reach agreement on price and other terms so that the transfer of ownership or possession can be affected.

\section{Financing}

According to Kotler (2003), marketing channels acquire the funds to finance inventories at different levels in the marketing channel. Because this financing function is one of the factors for the availability of products in distribution channels, distribution channel members need to pay attention to the basis for forming distribution costs (McDaniel and Keegan, 1999):

- Amenities

- Stock

- Transportation

- Communication

- Unitization

\section{Taking Risk}

Distribution channel members take on several risks associated with distributing the product from the company to the end customer. Furthermore, according to Saladin (1996), the risk-taking function of distribution channel members is related to the estimation of risks associated with the implementation of distribution channel work. Some of the risks that are usually borne by members of the distribution channel include: order processing, inventory storage, the amount of inventory stored and the delivery of ordered goods to customers (Dharmmesta, 1999 and Kotler, 2002).

\section{Physical}

Distribution channel members control the continuous storage and movement of physical products from raw materials to final customers. Physical functions carried out by members of the distribution channel are related to storage of goods and transportation (Saladin, 1999). In relation to transportation/transportation, Kotler (2002) states that distribution channel members need to pay attention to transportation decisions. The choice of transportation will affect product pricing, on-time delivery performance, and the condition of the goods when they arrive at their destination, all of which will affect customer satisfaction. Furthermore, according to McDaniel et al. (2001), distribution channels generally choose a transportation model based on several criteria:

- Cost (cost)

- Transit time (transit time)

- Reliability (reliability)

- Capability (capability)

- Reach (accessibility)

- Search (traceability)

\section{Payment}

According to Kotler (2003), marketing channels provide for buyer's payment of their bills through banks and other financial institutions. Then according to Saladin (2002), payment is the flow of payments/money to sellers for services or products that have been delivered. There are two payment methods that can be provided by distribution channels to customers (Purwosutjipto, 1992):

\section{- How to "Cash Payment"}

- Credit way

\section{Ownership}

The last function performed by distribution channel members is the ownership function. According to Kotler (2003), marketing channels oversee the actual transfer of ownership from one organization or person to another. Furthermore, according to Saladin (2002), ownership is the flow of ownership from a marketing agency to another. This function is very important because it is this function that determines whether the goods have arrived at the end consumer or not. If the goods have arrived in the hands of the end consumers, then the implementation of distribution channel activities from the company to the end consumers can be said to be complete.

Therefore, an effective distribution channel, certainly can further support the implementation of effective marketing as well. To be able to carry out distribution activities effectively, distribution 
channel members need to pay attention to the nine distribution channel functions they perform. (Management \& Suwarno, 2006)

- With the information function, distribution channels can identify customers, competitors and suppliers.

- With the promotion function, distribution channels can introduce products to customers as well as persuade them to buy them.

- With the negotiation function, the distribution channel can reach final agreements on prices and other matters relating to bids, so that transfer of ownership rights can be carried out.

- With the ordering function, distribution channels can immediately respond to customer needs, by placing orders at the warehouse or factory.

- With the financing function, distribution channels can determine the basis for forming costs and their efficiency.

- With the risk taking function, distribution channels can estimate what risks are faced in connection with the implementation of distribution activities.

- With physical functions, distribution channels can manage the continuity of storage and movement of physical products from raw materials to end customers.

- With the payment function, the distribution channel can provide services (media and means) of payment to customers.

\section{Methods}

This study uses a qualitative method, which is a research and understanding process based on a methodology that investigates a social phenomenon and human problems. Moleong (2007: 3) suggests that qualitative methods are research procedures that produce descriptive data in writing and orally from people and observed behavior.

The method of implementing the Food Distribution study activities in Depok City used a system of interviews, surveys and literature studies for 1 month. Esterberg (2002) in Sugiyono (2012: 410 - 411) defines the interview as follows "a meeting of two persons to exchange information and idea through questions and responses, resulting in communication and joint construction of meaning about a particular topic". An interview is a meeting of two people to exchange information and ideas through question and answer, so that meaning can be constructed in a particular topic. In qualitative research, it often combines participatory observation techniques with in-depth interviews. During the observation, the consultant team also conducted interviews with the people in it (Sugiyono 2012: 412). The samples in this study were not named as respondents, but as resource persons, participants, or informants. The informants in this study are those who are distributors of food raw materials. The informants of this research distribute their products in the city of Depok. In the context of data collection, there are 3 (three) process activities carried out in this study, namely:

- The process of entering the study location (Getting In). In accordance with Moleong's opinion that: Informant legitimacy comes from their overall ability to convey an acceptable and true presence ( Informant legitimacy comes from the overall ability of researchers to convey an acceptable and trustworthy presence ).

- When at the study location (Getting along). Moleong stated that ... a key to achieving accuracy and comprehensiveness is to build trust with respondents ... (building trust with respondents is the key to success in achieving and obtaining accuracy and comprehensiveness).

- Data collection (Logging the data)

Compilation and tabulation of data using interview data using the type of food distribution channel, consisting of 2 types:

\section{Direct to Suppliers}

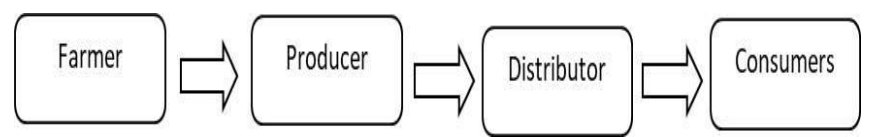

Figure 1. Single Distribution Channel

2. Direct to Traditional Markets 


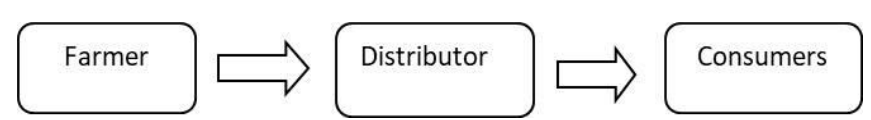

Figure 2. Traditional Distribution Channels

The single distribution channel chain starts from the farmer and then is purchased and processed by the producer into a finished product after which it is distributed to distributors, either in the form of agents or new retailers into the hands of consumers as shown in Figure 1. Figure 3 show the traditional distribution channel where chain starts from farmers and is directly processed and packaged by farmers into finished products after which they are distributed to distributors either in the form of agents or new retailers into the hands of consumers.

Table 1. Supply needs of the 5 main ingredients

\begin{tabular}{cccccc}
\hline No. & Commodities & Production & Consumption & $\begin{array}{c}\text { Shortage of } \\
\text { Supply }\end{array}$ & Supply \\
\hline 1 & Rice & $1,518,000$ & $2,687,136,137$ & $1,169,136$ & $11,534,750$ \\
2 & Red onion & 0 & $1,063,304,316$ & $1,063,304,31$ & $55,504,925$ \\
& & & & 6 & \\
3 & Red chili pepper & 0 & $96,370,633$ & $96,370,633$ & $23,248,925$ \\
4 & Beef & $7,906,444$ & $43,504,140$ & $7,862,940$ & $4,346,200$ \\
5 & Chicken Race & $3,632,149$ & $464,481,663$ & $3,167,667$ & $11,310,000$ \\
\hline
\end{tabular}

\section{Results and Discussions}

Based on the results of this study, the supply needs of the 5 main ingredients, namely : Rice, Red onion, Red chili pepper, Beef and Chicken Race can be presented in Table 1 .

In general, the source of rice supply in Depok City comes from Karawang and Cipinang Central Market, although there are some suppliers directly from the Sawangan, Beji and Depok areas 2. Large, large, medium and small wholesalers generally buy rice directly from Karawang, while for shops rice with a small turnover of 1 to 2 tons / day buys the Cipinang Central Market. Based on the observations and information obtained, in Depok City, the daily rice stock is $32,700 \mathrm{~kg}$ or 32.7 tons per day, so that in a year as much as $11,534,750 \mathrm{~kg}$. The source of supply of Red Chili in Depok City is mainly from the Kramat Jati Main Market. Although there are also traders who are directly related to large traders from Blitar and Banyuwangi. The source of supply from Kramat Jati Market is more of an option given its more certain availability and low prices. Entrepreneurs who bought into the Market Master $\mathrm{K}$ ramat $\mathrm{J}$ ati vary either wholesalers, secondary wholesalers and small wholesalers. Ease of transportation makes the business actors get access to relatively equal in reaching the Market Master $\mathrm{K}$ ramat $\mathrm{J}$ ati and some in Kemang Bogor Market and Central Market Cibitung-Bekasi. Based on observations and information obtained, in Depok City, the stock of red chilies per day is $64,580 \mathrm{~kg}$ or 64.58 tons per day, so that in a year as much as $23,248,925 \mathrm{~kg}$. The source of supply of shallots in Depok City is mainly from the Kramat Jati Main Market. Although there are also traders who are directly related to large traders from Brebes. The source of supply from Kramat Jati Market is more of an option given its more certain availability and low prices.

Entrepreneurs who bought into the Market Master Kramat Jati vary either wholesalers, secondary wholesalers and small wholesalers. Ease of transportation makes the business actors get access to relatively equal in reaching the Market Master K ramat J ati and Market Master CibitungBekasi. In general, the source of supply for the City of Depok's Shallots comes from Kramat Jati Market and Bogor's Kemang Market, which they directly get from farmers in Brebes and Nganjuk areas Based on observations and information obtained, in Depok City, the stock of shallots per 
day is $154,180 \mathrm{~kg}$ or 154.18 tons per day, so that in a year as much as $55,504,925 \mathrm{~kg}$. Beef beef distribution in Depok city through several trade networks. In general, fresh chicken in the market are traditionally derived from RP $\mathrm{H}$ (Slaughterhouse Animal ) scattered small lots in the city of Bogor, among others on the RPH Tapos Bogor and Cibinong are generally directly from the farmers. Based on observations and information obtained, in Depok City, the stock of Beef Beef per day is $12,070 \mathrm{~kg}$ per day, so that in a year as much as 4,346,200 kg.

Distribution of purebred chicken in Depok city through several trade networks. In general, fresh chicken circulating in traditional markets comes from small RPU (Poultry Slaughterhouses) which are widely scattered in Depok City, including in HBTB Arja Mukti Depok, Kranggan and Cilangkap, which are generally directly from farmers. Based on the observations and information obtained, in Depok City, the stock of purebred chicken meat per day is 31,417 head per day, so that in a year as many as 11,310,000 head.

\section{Acknowledgement}

The authors thank to Kepala Dinas Ketahanan Pangan, Pertanian \& Peternakan Kota Depok, Kepala Bidang Pertanian DISTANKAN Kota Depok, Survey Team from Local Government Kota Depok, Data Enumerator Team from BPS Kota Depok and Translator Team who have supported this research to be conducted successfully.

\section{Conclusion}

To anticipate price volatility, the Depok City Government, which is in charge of Food Security and Trade, needs to have a communication network with business actors in production centers of staple food. This is to monitor the conditions of supply available in the producer area. Apart from this, it is also necessary to establish communication with distribution business actors in Depok City who have a strong influence in the trade of food commodities; And there must be good cooperation between the central government, local government and farmers specifically for the main raw materials of the community so that this food distribution channel will be well maintained so that there will be no shortage of main raw materials in the community because there is direct anticipation carried out by the government.

\section{References}

[1] Bowersox, Donald J. 2006. Logistics Management, Integration of Physical Distribution Management Systems and Materials Management. PT. Bumi Aksara, Jakarta.

[2] Dharmmesta, BS 1999. Marketing Channels: Concepts and Strategies of Quantitative Analysis . Yogyakarta: BPFE-Yogyakarta

[3] Komaruddin. 1994. Encyclopedia of Management. Second edition. Jakarta: Earth Literacy.

[4] Kotler, Armstrong, 1997. Marketing Basics (Translation) . Edition 7e. Jakarta: Erlangga.

[5] Kotler, P. 2002. Marketing Management (Translation) . Millennium edition 2. Jakarta: Prenhallindo.

[6] Kotler, P. 2003. Marketing Management . Elevent edition. Upper Saddle River, New Jersey: Prenticehall.

[7] Keegan, Warren.J, 2003. Distribution Channels; All Management Insight, Lecture Notes.

http://www.informasiku.com/2011/04/salurandistribution-definisi-fungsi-dan.html

Accessed: December 5, 2012.

[8] Kotler, Philip, 1991. Channels of Distribution; All Management Insight, Lecture Notes. http://www.informasiku.com/2011/04/salurandistribution-definisi-fungsi-dan.html Accessed: December 5, 2012.

[9] McCarthy, JE 1985. Marketing Basics (Translation) . Jakarta: Erlangga.

[10]McDaniel, Keegan. W. 1999. Marketing Plans that Work (Translation) . Jakarta: Erlangga.

[11]McDaniel et al . 2001. Marketing (Translation). Second book. Jakarta: Salemba 4. 
[12]Nitisemito, 1993. Distribution Channels; All Management Insight, Lecture Notes. http://www.informasiku.com/2011/04/salurandistribution-definisi-fungsi-dan.html Accessed: December 5, 2012.

[13]Purwosutjipto, 1992. The Main Definition of Indonesian Commercial Law . Volume 4. Jakarta: Djambat.

[14]Saladin, D, 1996. Core Elements of Marketing and Marketing Management . Bandung: CV.Mandar Maju.

[15]Saladin, D, 2002. Marketing Management: Analysis, Planning, Implementation and Control . Bandung: Linda Karya.

[16]Gun, G., \& Karlina, Y. (2011). The Effect of Distribution Costs and Distribution Channels on Sales Volume. Vol 10 (September 2010), 151-175.

[17]Hahury, HD (2010). The Determination of Oven Distribution Channels In Ud. Swan Jaya In The City Of Ambon Hendri . Iv (12-21).

[18]Ika Lis Mariatun, MP (2017). The Influence of Distribution Channels, Prices and Promotions on Sales Volume at Home Industry Tempe Putra Kl, Socah District, 2016. Journal of Science and Education, Social-Economy ISSN (2597-7806) , 1 (1), 31-45.

[19]Management, J., \& Suwarno, HL (2006). The Nine Distribution Channels Functions: Key to Implementing Activities . 6 (1), 79-87.

[20]Tulong, SR, Tumbel, AL, \& Palandeng, ID (2016). Identification of Distribution Channels in the Potato Supply Chain in Modoinding District (Study in Linelean Village). EMBA Journal , 4 (1), 1562-1569. https://doi.org/ISSN 2303-1174.

[21]Sugiyono, 2012. Educational research: quantitative, qualitative, and R\&D approaches. CV Alfabeta, Bandung. 
PSYCHOLOGY AND EDUCATION (2021) 58(1): 4164-4172

An Interdisciplinary Journal 